\title{
The Uses of a Bachelor's Degree in Sociology: Careers of Recent Graduates of a Maritime University
}

\author{
HELEN RALSTON*
}

\begin{abstract}
What happens to sociology graduates? A mailed questionnaire follow-up study of 267 recent graduates of a maritime university revealed that most of them continue their education in a professional or semi-professional school, usually a school of education or a school of social work. A high proportion of graduates, especially women, become teachers. Many obtain jobs in social welfare agencies, whether or not they continue their education. A small percentage without further education get jobs as research workers for government departments. The women all seem to be oriented to work outside the home, even if presently unemployed. They tend, however, to be in traditional "women's occupations" or "semi-professions," and rarely in supervisory or administrative positions.

The graduates in sociology of this maritime university come in high proportions from blue-collar backgrounds. They tend to see their own careers as being upwardly mobile through normal progression to administrative, supervisory, and managerial positions in the educational, social service, and public service sectors of society. They are also geographically mobile, but most migration is within the province or the region.

The results are compared with the findings of another study of the careers of 1976 and 1977 graduates in other disciplines and faculties of the same university. Some of the policy implications of the study, (from the perspectives of students, teachers, administrators, and governments) are discussed.
\end{abstract}

\section{RÉSUMÉ}

Les fonctions d'un diplôme en sociologie: Carrières des diplômes recents d'une université des provinces maritimes

Les diplômés en sociologie, que leur arrive-t-il? Un questionnaire envoyé comme suivi à 267 diplômés récents d'une université des provinces maritimes révèle que la plupart

* Assistant Professor, Department of Sociology, Saint Mary's University. 
d'entre eux poursuivent leur formation dans une école professionnelle ou seim-professionnelle, d'habitude une faculté de pédagogie ou une école de formation pour travailleurs sociaux. Une proportion élevée de diplômés, en particulier des fermes, deviennent des enseignants. Beaucoup d'entre eux trouvent des emplois dans des agences de bien-être social, s'ils continuent ou pas leurs études. Un petit pourcentage d'entre eux sans formation ultérieure trouvent des emplois en tant que travailleurs sociaux auprès des ministères gouvernementaux. Les femmes semblent toutes s'orienter vers un travail en dehors de leur maison, même lorsqu'elles sont actuellement sans emploi. Elles ont tendance, toutefois, de se trouver dans des "emplois réservés à la femme" ou des métiers dans les marges des professions libérales. Elles occupent rarement des postes administratifs ou de superviseurs.

Les diplomés en sociologie de cette université des provinces maritimes proviennent en haute proportion des cols bleus. Ils ont tendance d'envisager leurs propres carrières comme mobiles et à la hausse en progressant de façon normale, dans les secteurs de l'enseignement, des services sociaux et de la fonction publique, des postes administratifs à ceux de surveillance et de gestion. Ils sont également mobiles sur le plan géographique - en se mutant le plus souvent à l'intérieur de la province ou de la région.

On compare les présents résultats à ceux d'une autre étude sur les carrières des diplômés (1976 et 1977) dans d'au tres disciplines de la même université. Il s'agit de certaines implications de l'étude quant à l'orientation de la politique (les perspectives des étudiants, des enseignants, des administrateurs et des gouvernements).

\section{THE PROBLEM}

It is common knowledge that until the early 1960's a university degree more or less guaranteed employment in one's area of study or occupational choice. The educational expansion of the 1960's together with changes in the state of the economy and in the occupational structure of society have made employment upon graduation with a first degree anything but certain, and a job in line with one's field of study extremely problematic.

Almost ten years ago, under the impact of tremendous expansion in enrolments and in university budgets, the Association of Atlantic Universities commissioned a study of higher education in the Atlantic Provinces with a view to formulating recommendations to universities and to governments for the wise and efficient use of public funds in the 1970's (Crean, 1969: 17). While recognizing the existence of different conceptions of the role of the university, the resultant report accepted as a basic assumption that university education is perceived by students primarily in terms of its economic relevance and its adequacy as preparation for a career (Crean, 1969: 12-13). The report acknowledged the criterion of economic relevance to be less appropriate in the humanities and social sciences where education was rarely conceived as a preparation for any specific career outside the teaching profession; nevertheless, at a time of economic prosperity and relatively low unemployment, higher education was generally accepted as a profitable investment for the future and insurance against unemployment. Hence the emphasis of the recommendations of the report was on ensuring increased participation rates in university education in the belief that the provision of educational opportunity (at the higher educational level) would be a key factor in overcoming regional disparity (Crean, 1969: 77). The study projected a 
continuing expansion in university education in the decade up to 1980 , particularly in terms of female and graduate enrolments, with a doubling of enrolments and participation rates for the 18.24 age category to $17.7 \%$ in 1975 and $20.8 \%$ in 1980 for the Atlantic universities. Actual participation rates of the 18-24 age category in post-secondary education in the Atlantic region for 1975 are $13.8 \% .^{1}$

In the 1969 study of the Association of Atlantic Universities apparently no account was taken of possible changes in the state of the economy and the job market and of possible devaluation in the currency of a university degree with increasingly higher universiiy participation rates. Today undergraduate students are becoming more and more skeptical of the returns from a university degree. Moreover, both governments and universities are more than ever faced with the issue of "wise and efficient use of public funds." Hence the humanities and social sciences, never primarily oriented to preparation for the world of work, are the object of increasing attention from students, university administrators, and governments alike in terms of their economic and social relevance.

The present study focuses on one discipline in the social sciences, sociology, and students who have chosen to major in this discipline with a view to providing some "hard data" on the relation between educational and occupational careers which could be significant for university curriculum planning and policy decisions.

Each year students majoring in sociology ask, "What can I do with a major in sociology?" Their professors try to answer as best they can, outlining the personal arid social advantages of a degree in sociology, and indicating the possible job opportunities. Few follow-up studies have been made of the student population: the actual jobs sociology graduates get after graduation, where they get them, and the factors that influence these job outcomes. Awareness of the lack of these kinds of data prompted a follow-up study of sociology graduates of a maritime university for the years 1971 to 1977 , inclusive. The data were gathered through a mailed questionnaire in January/February, 1978. In all, 267 graduates were surveyed; 125 responses were received and used for analysis (a response rate of approximately $47 \%$ ).

\section{FINDINGS}

\section{What happens to sociology graduates?}

\section{Post-graduate education}

According to the present study, most of the graduates continue their education in a professional or semi-professional school, usually a school of education or a school of social work. Seventy per cent of the graduates have pursued further education, the vast majority at university. There is no great difference between males and females, although males have a slightly higher proportion continuing their education than females. Most females (71\%) have continued their studies in education. One third of the respondents with further education have a Bachelor's degree in education; moreover, a further $6 \%$ have Master's degrees in education, and 5\% have various educational certificates, some beyond the B.Ed. level. One third of the male respondents with further education have also continued their studies in education; on the other hand, twice as many males as females have studied at a school of socieal work (15\% as compared to $7 \%$ ). Thus the evidence suggests that an arts 
TABLE 1

DISTRIBUTION OF RESPONDENTS WITH FURTHER EDUCATION BY KIND OF POST-GRADUATE SCHOOL ATTENDED, BY SEX

\begin{tabular}{|c|c|c|c|}
\hline $\begin{array}{l}\text { Post-graduate } \\
\text { school }\end{array}$ & $\begin{array}{l}\text { Males } \\
(\mathrm{N}=46)\end{array}$ & $\begin{array}{c}\text { Females } \\
(N=4)\end{array}$ & $\begin{array}{l}\text { Total } \\
(N=87)\end{array}$ \\
\hline Sociology & $\begin{array}{l}4.4 \\
(2)\end{array}$ & $\begin{array}{l}2.4 \\
(1)\end{array}$ & $\begin{array}{l}3.4 \\
(3)\end{array}$ \\
\hline Social Work & $\begin{array}{l}15.2 \\
(7)\end{array}$ & $\begin{array}{l}7.3 \\
(3)\end{array}$ & $\begin{array}{l}11.5 \\
(10)\end{array}$ \\
\hline Law School & & $\begin{array}{l}4.9 \\
(2)\end{array}$ & ${ }^{2.3}{ }^{3}$ \\
\hline Theologica1 & $\begin{array}{l}13.0 \\
(6)\end{array}$ & & $\begin{array}{l}6.9 \\
(6)\end{array}$ \\
\hline Education & $\begin{array}{l}32.6 \\
(15)\end{array}$ & $\begin{array}{l}70.8 \\
(29)\end{array}$ & $\begin{array}{l}50.6 \\
(44)\end{array}$ \\
\hline Other university & $\begin{array}{l}8.7 \\
(4)\end{array}$ & $\begin{array}{l}2.4 \\
(1)^{4}\end{array}$ & $\begin{array}{l}5.7 \\
(5)\end{array}$ \\
\hline Teachers College & & ${ }^{4.9}$ & ${ }_{(2)}^{2.3}$ \\
\hline Nursing School & & $\begin{array}{l}2.4 \\
(1)^{4}\end{array}$ & ${ }_{(1)}^{1.2}$ \\
\hline Institute of Technology & ${ }_{(1)}^{2.2}$ & & ${ }_{(1)}^{1.2}$ \\
\hline other & $\begin{array}{l}23.9 \\
(11)\end{array}$ & $\begin{array}{l}4.9 \\
(2)\end{array}$ & $\begin{array}{l}14.9 \\
(13)\end{array}$ \\
\hline Total & $100.0 \%$ & $100.0 \%$ & $100.0 \%$ \\
\hline
\end{tabular}

degree with a major in sociology serves predominantly as a preparation for a teaching career, and for a career in social work. Very few from this maritime university (only 3 respondents) pursue a graduate career in sociology. Table 1 presents the data on the kinds of post-graduate schools attended by the respondents.

\section{Work Status}

Virtually all of the graduates have worked at some time (92\% of both male and female respondents). However, for whatever reason, there are differences between the sexes in current employment status. Whereas $82 \%$ of the males are currently working, only $75 \%$ of the females are working. "Not working" does not necessarily mean "unemployed," as Table 2 indicates: of 15 females not working, 8 are full-time students; of 11 males not working, 10 are full-time students. 
TABLE 2

OCCUPATION BY POST-GRADUATE EDUCATION, BY SEX

\begin{tabular}{|c|c|c|c|c|c|c|c|c|c|}
\hline \multirow{2}{*}{ Occupation } & \multicolumn{3}{|c|}{$\begin{array}{l}\text { All respondents } \\
\text { Post-grad education }\end{array}$} & \multicolumn{3}{|c|}{$\begin{array}{c}\text { Males } \\
\text { Post-grad education }\end{array}$} & \multicolumn{3}{|c|}{$\begin{array}{c}\text { Females } \\
\text { Post-grad education }\end{array}$} \\
\hline & $\begin{array}{l}\text { Yes } \\
(\mathrm{N}=87)\end{array}$ & $\begin{array}{c}\text { No } \\
(\mathrm{N}=34)\end{array}$ & $\begin{array}{l}\text { Row tot } \\
(\mathrm{N}=121)\end{array}$ & $\begin{array}{c}\text { Yes } \\
(\mathrm{N}=46)\end{array}$ & $\begin{array}{c}\text { No } \\
(\mathrm{N}=17)\end{array}$ & $\begin{array}{l}\text { Row tot } \\
(\mathrm{N}=63)\end{array}$ & $\begin{array}{l}\text { Yes } \\
(N=41)\end{array}$ & $\begin{array}{c}\text { No } \\
(N=17)\end{array}$ & $\begin{array}{l}\text { Row tot } \\
(\mathrm{N}=58)\end{array}$ \\
\hline $\begin{array}{l}\text { Manager } \\
\quad \text { (trade, finance, } \\
\text { transp. communic.) }\end{array}$ & $\begin{array}{l}6.9 \\
(6)\end{array}$ & $\begin{array}{l}5.9 \\
(2)\end{array}$ & $(8)$ & $\begin{array}{l}13.0 \\
(6)\end{array}$ & $\frac{11.8}{(2)}$ & $\begin{array}{r}12.7 \\
(8)\end{array}$ & & & \\
\hline Teacher & $\begin{array}{l}37.9 \\
(33)\end{array}$ & $\begin{array}{l}8.8 \\
(3)\end{array}$ & $\begin{array}{l}29.8 \\
(36)\end{array}$ & $(11)^{23}$ & ${ }_{(I)}^{5.9}$ & $\begin{array}{l}19.0 \\
(12)\end{array}$ & $\begin{array}{r}53.8 \\
(22)\end{array}$ & $\begin{array}{r}11.8 \\
(2)\end{array}$ & $\begin{array}{l}41.4 \\
(24)\end{array}$ \\
\hline Religion, health & $\begin{array}{l}4.6 \\
(4)\end{array}$ & & $\begin{array}{l}3.3 \\
(4)\end{array}$ & $(3)^{6}$ & & $\begin{array}{l}4.8 \\
(3)\end{array}$ & $\begin{array}{l}2.4 \\
(1)\end{array}$ & & $\begin{array}{l}1.7 \\
(1)\end{array}$ \\
\hline Social welfare & $\begin{array}{l}18.5 \\
(16)\end{array}$ & $\begin{array}{l}61.8 \\
(21)\end{array}$ & $\begin{array}{l}30.6 \\
(37)\end{array}$ & $\left.{ }^{21.8}\right)^{8}$ & $\begin{array}{l}58.8 \\
(10)\end{array}$ & $\begin{array}{l}31.7 \\
(20)\end{array}$ & $\begin{array}{l}14.6 \\
(6)\end{array}$ & $\begin{array}{l}64.7 \\
(11)\end{array}$ & $\begin{array}{r}29.4 \\
(17)\end{array}$ \\
\hline $\begin{array}{l}\text { Other professional } \\
\text { (economist, accountant } \\
\text { statistician) }\end{array}$ & $\begin{array}{l}4.6 \\
(4)\end{array}$ & & $\begin{array}{l}3.3 \\
(4)\end{array}$ & $\begin{array}{l}6.5 \\
(3)\end{array}$ & & $\begin{array}{l}4.8 \\
(3)\end{array}$ & $\begin{array}{l}2.4 \\
(1)\end{array}$ & & $\begin{array}{l}1.7 \\
(1)\end{array}$ \\
\hline Clerical, sales & $\begin{array}{l}3.4^{4} \\
(3)\end{array}$ & $\begin{array}{l}14.7 \\
(5)\end{array}$ & $\begin{array}{l}6.6 \\
(8)\end{array}$ & $\begin{array}{l}2.2 \\
(1)\end{array}$ & $\begin{array}{l}11.8 \\
(2)\end{array}$ & $\begin{array}{l}4.8 \\
(3)\end{array}$ & $\begin{array}{r}4.9 \\
(2)\end{array}$ & $\begin{array}{l}17.6 \\
(3)\end{array}$ & $\begin{array}{r}8.6 \\
(5)\end{array}$ \\
\hline Service and communications & $\begin{array}{l}2.3 \\
(2)\end{array}$ & $\begin{array}{l}8.8 \\
(3)\end{array}$ & $\begin{array}{l}4.1 \\
(5)\end{array}$ & $\begin{array}{l}4.3 \\
(2)\end{array}$ & $\begin{array}{l}11.8 \\
(2)\end{array}$ & $\begin{array}{l}6.3 \\
(4)\end{array}$ & & $\begin{array}{l}5.9 \\
(1)\end{array}$ & $\begin{array}{l}1.7 \\
(1)\end{array}$ \\
\hline Housework & $\begin{array}{l}1.1 \\
(1)\end{array}$ & & (1) & & & & $\begin{array}{l}2.4 \\
(1)\end{array}$ & & $\begin{array}{l}1.7 \\
(1)\end{array}$ \\
\hline Student & $\begin{array}{l}20.7 \\
(18)\end{array}$ & & $\begin{array}{l}14.9 \\
(18)\end{array}$ & $\begin{array}{l}21.8 \\
(10)\end{array}$ & & $\begin{array}{l}15.9 \\
(10)\end{array}$ & $\begin{array}{l}19.5 \\
(8)\end{array}$ & & $\begin{array}{r}13.8 \\
(8)\end{array}$ \\
\hline TOTAL & $100.0 \%$ & $100.0 \%$ & $100.0 \%$ & $100.0 \%$ & $100.0 \%$ & $100.0 \%$ & $100.0 \%$ & $100.0 \%$ & $100.0 \%$ \\
\hline $\begin{array}{l}\text { Chi square = } \\
\text { Significance }=\end{array}$ & & $\begin{array}{c}39.79600 \\
.0000\end{array}$ & & & $\begin{array}{l}6.89802 \\
.0181\end{array}$ & & & $\begin{array}{c}24.62214 \\
.0009\end{array}$ & \\
\hline
\end{tabular}




\section{Occupation}

In terms of the kinds of careers the graduates have pursued, the data show a clustering of the respondents in two major occupational categories: (1) teaching, and (2) a variety of occupations I have categorized as "social welfare." The term "social welfare" includes two sub-categories, (a) social workers (with or without a post-graduate degree), case-aides, counselors (not in schools), community workers, human rights officers, youth workers, etc., and (b) correctional workers (with or without a post-graduate degree), including correctional officers (prison guards), parole officers, probation officers. In all, $60 \%$ of the graduates work in these two occupational categories of teaching and social welfare and are equally distributed between them. Females, however, are overwhelmingly represented in the teaching profession, and they are usually teaching at the elementary or junior high level. A relatively high proportion ( $9 \%$ ) of the female respondents are employed in traditionally female clerical and sales occupations.

A striking finding is that $62 \%$ of the graduates who have no further education beyond their B.A. degree are in various types of social welfare jobs: in social research or work with handicapped, socially deprived, deviant and other minority individuals and groups. Apparently the sociology programme has either selected students whose occupational aspirations have led them into such careers, or provided them with the kind of degree which opens up such job opportunities, or both.

The women graduates in sociology from this maritime university are rarely in any kind of supervisory or administrative role, and none can be classified as owners or managers in the conventional census classificatory system. In contrast, $13 \%$ of the male graduates are in managerial positions, working in finance, retail trade, service, advertising, transportation and communications; three-quarters of these graduates have post-graduate education.

\section{What are the graduates' attitudes towards sociology?}

The study was designed to gather graduates' perceptions of the contribution of their major in sociology to obtaining their present job and to their general work and life experience. Among the 102 graduates who have jobs, $60 \%$ of the males consider that sociology helped them get their job, whereas only $43 \%$ of the females consider that it helped. These results are related to the concentration of males in social welfare occupations and of females in teaching. Nearly $90 \%$ of both males and females in the social welfare occupations perceive their sociology major to have helped them get their job. Of those in the teaching occupations, over half the males (in contrast to the females) perceive a sociology major to have been helpful. In large measure this may be accounted for by the areas in which they teach; males are found in areas such as communications with Manpower upgrading, human growth and development at an institute of technology, community school co-ordination, and special education programmes; females, on the other hand, are elementary and junior high school teachers, and several are substitute teachers. Virtually all the graduates (95\% of the males and $92 \%$ of the females) perceive that sociology courses have contributed to their general work and/or life experience. The respondents were asked in an open-ended question to specify in what way this has occurred. The kinds of responses that recur are as follows: 


\section{Contribution of sociology}

"Better equipped to deal with all sorts of people on a day to day basis"

"Understanding of different cultural values in rural communities"

"Opened my mind"

"Interpersonal skills; more respecting of other people"

"Understanding people, staff problems, dealing with customers on different levels"

"Application of management principles, analysis of social impact of programs, building theoretical models"

"Broadened my perspective"

"Helped me understand people from lower socioeconomic background; their attitudes and goals in life"

"Broadened understanding of what is going on in local communities"

"Helped me to look at data and draw valuable information, especially to get funding"

"Gave me a holistic perspective, an analy tical framework; to become a learning person and not a learned person"

"Critical analysis of social realities; aided in solving, explaining, uncovering difficulties in work"

"Ability to write well and analyse situations"

"A perspective on present day events, a better grasp and skills in teaching"

"Helped create understanding that there is more than meets the eye; not to make "moral' judgements"

\section{Occupation}

Insurance sales V.P.

Priest

Community residence worker

Revenue collector

Banker

Analyst of energy

requirements

Urban planner

Teacher in adjusted

programme

Teacher-primary

Youth worker in social agency

Director of mental health

clinic

Staff worker in institute of mental retardation

Research worker, social development

Teacher of English and social studies

Student counsellor

The open-ended responses of the graduates have been coded according to five general categories: (1) broad perspective on society, (2) understanding of people and life, (3) skills in research, problem definition, and analysis, (4) direct job preparation, and (5) yes, but no reason given. These categories have been reduced to three categories for data analysis, by combining the first two categories into (1) understanding of people and life in society, and the third and fourth categories into (2) job preparation, skills in research methods. The results, together with an analysis of the relationship between the perception of sociology's contribution to work/life experience and the present occupation of the graduate, are presented in Table 3 . Here we see that for both male and female graduates in most occupations, but especially in teaching (where a high proportion are concentrated), sociology is perceived above all as giving a broad understanding of people and of life and society in general. It is those in the various social welfare occupations who perceive it as being directly related to their job and providing them with skills they need at work. Of course the data do not tell us whether or not we are selecting into our undergraduate 
TABLE 3

PRESENT OCCUPATION BY CONTRIBUTION TO WORK/LIFE EXPERIENCE, BY SEX

\begin{tabular}{|c|c|c|c|c|c|c|c|c|c|c|}
\hline \multirow[b]{2}{*}{$\begin{array}{l}\text { Sociology's } \\
\text { contribution }\end{array}$} & \multicolumn{9}{|c|}{ Occupational category } & \multirow[b]{2}{*}{$\begin{array}{l}\text { Row } \\
\text { Total }\end{array}$} \\
\hline & Manager & Teacher & $\begin{array}{l}\text { Religion, } \\
\text { Health }\end{array}$ & $\begin{array}{l}\text { Social } \\
\text { Welfare }\end{array}$ & $\begin{array}{c}\text { Other } \\
\text { professlonal }\end{array}$ & $\begin{array}{l}\text { Clerical, } \\
\text { sales }\end{array}$ & $\begin{array}{l}\text { Service, } \\
\text { communfication }\end{array}$ & Housework & Student & \\
\hline Total & $\begin{array}{c}(\mathrm{N}=8) \\
\%\end{array}$ & $\begin{array}{c}(\mathrm{N}=34) \\
\%\end{array}$ & $\begin{array}{c}(N=4) \\
\%\end{array}$ & $\begin{array}{c}(\mathrm{N}=35) \\
\%\end{array}$ & $\begin{array}{c}(N=4) \\
\%\end{array}$ & $\begin{array}{c}(\mathrm{N}=7) \\
\%\end{array}$ & $\begin{array}{c}(\mathrm{N}=5) \\
\%\end{array}$ & $\begin{array}{c}(N=1) \\
\%\end{array}$ & $\begin{array}{c}(\mathrm{N}=16) \\
\%\end{array}$ & $\begin{array}{c}(N=114) \\
\%\end{array}$ \\
\hline $\begin{array}{l}\text { Understanding people, } \\
\text { life, soclety }\end{array}$ & 75.0 & 73.5 & 100.0 & 28.6 & 75.0 & 57.1 & 80.0 & 100.0 & 43.8 & 56.1 \\
\hline $\begin{array}{l}\text { Job, research, } \\
\text { skills }\end{array}$ & 25.0 & 20.6 & & 54.3 & 25.0 & 14.3 & & & 37.5 & 31.6 \\
\hline No reason given & & 5.9 & & 17.1 & & 28.6 & 20.0 & & 18.7 & 12.3 \\
\hline Tota1 & $100.0 \%$ & $100.0 \%$ & $100.0 \%$ & $100.0 \%$ & $100.0 \%$ & $100.0 \%$ & $100.0 \%$ & $100.0 \%$ & $100.0 \%$ & $100.0 \%$ \\
\hline Males & $\begin{array}{c}(N=8) \\
\%\end{array}$ & $\begin{array}{c}(N=12) \\
\%\end{array}$ & $\begin{array}{c}(\mathrm{N}=3) \\
\%\end{array}$ & $\begin{array}{c}(\mathrm{N}=19) \\
\%\end{array}$ & $\begin{array}{c}(\mathrm{N}=3) \\
\%\end{array}$ & $\begin{array}{c}(\mathrm{N}=3) \\
\%\end{array}$ & $\begin{array}{c}(\mathrm{N}=4) \\
\%\end{array}$ & & $\begin{array}{c}(\mathrm{N}=9) \\
\%\end{array}$ & $\begin{array}{c}(N=61) \\
\%\end{array}$ \\
\hline $\begin{array}{l}\text { Understanding people, } \\
\text { life, society }\end{array}$ & 75.0 & 75.0 & 100.0 & 42.1 & 66.7 & 66.7 & 75.0 & & 33.3 & 59.0 \\
\hline $\begin{array}{l}\text { Job, research, } \\
\text { skills }\end{array}$ & 25.0 & 16.7 & & 47.4 & 33.3 & & & & 55.6 & 31.1 \\
\hline No reason given & & 8.3 & & 10.5 & & 33.3 & 25.0 & & 11.1 & 9.8 \\
\hline Total & $100.0 \%$ & $100.0 \%$ & $100.0 \%$ & $100.0 \%$ & $100.0 \%$ & $100.0 \%$ & $100.0 \%$ & & $100.0 \%$ & $100.0 \%$ \\
\hline Females & & $\begin{array}{c}(\mathrm{N}=22) \\
\%\end{array}$ & $\begin{array}{c}(\mathrm{N}=1) \\
\%\end{array}$ & $\begin{array}{c}(\mathrm{N}=16) \\
\%\end{array}$ & $\begin{array}{c}(\mathrm{N}=1) \\
\%\end{array}$ & $\begin{array}{c}(\mathrm{N}=4) \\
\%\end{array}$ & $\begin{array}{c}(\mathrm{N}=1) \\
\%\end{array}$ & $\begin{array}{c}(\mathrm{N}=1) \\
\%\end{array}$ & $\begin{array}{c}(\mathrm{N}=7) \\
\%\end{array}$ & $\begin{array}{c}(\mathrm{N}=53) \\
\%\end{array}$ \\
\hline $\begin{array}{l}\text { Understanding people, } \\
\text { life, society }\end{array}$ & & 72.7 & 100.0 & 12.5 & 100.0 & 50.0 & 100.0 & 100.0 & 57.1 & 52.8 \\
\hline $\begin{array}{l}\text { Job, research, } \\
\text { skills }\end{array}$ & & 22.7 & & 62.5 & & 25.0 & & & 14.3 & 32.1 \\
\hline No reason given & & 4.6 & & 25.0 & & 25.0 & & & 28.6 & 15.1 \\
\hline Total & & $100.0 \%$ & $100.0 \%$ & $100.0 \%$ & $100.0 \%$ & $100.0 \%$ & $100.0 \%$ & $100.0 \%$ & $100.0 \%$ & $100.0 \%$ \\
\hline
\end{tabular}


programmes in sociology people who are seeking these skills for jobs they aspire to, and have perhaps already worked in full-time or part-time. We may also be selecting students with a general interest in human behaviour. A recent study by Clinton and Kincaid (1977) showed this. In other words, graduates who maintain that sociology has given them a better understanding of the social behaviour of people from varying social backgrounds and of the structure and processes of social interaction may have been prompted to take sociology in the first place because of their interest in social behaviour.

A further test of the graduates' perceptions of the contribution of sociology to their work and/or life experience was included in an item asking: "If you could take your undergraduate studies over again, would you still major in sociology? If yes, why? If no, why not?" Seventy per cent of the females and $59 \%$ of the males stated that they would major again in sociology. Their responses have been categorized as positive and negative attitudes towards majoring again in sociology.

\section{Attitudes towards a majoring again in sociology:}

Negative responses included statements such as the following:

Changed interests (16\% of all male respondents; $9 \%$ of all female respondents)

"My interest lies in psychology"

"I have become interested in geography"

"I would have studies nursing"

"I am into religion"

Job relevance poor ( $20 \%$ of all male respondents; $19 \%$ of all female respondents)

"Limited application"

"Not useful for the business world"

"Commerce would be more beneficial"

"Economics would be more relevant in my job"

"No jobs available without graduate work"

"No future"

Positive responses included statements such as the following:

Enjoyment, interest, challenge (27\% of male respondents; $32 \%$ of female respondents)

"I enjoyed the learning experience very much"

"I found it a challenge"

"I learned a lot and am proud of the soc. dept. at..."

"I loved it"

Job relevance good ( $10 \%$ of the male respondents; $19 \%$ of the female respondents)

"It was most related to my career plans (as a social worker)"

"I hope to become a criminologist"

"It has benefited me greatly teaching (on an Indian reserve)"

"No other major could have helped me more (as an elementary school teacher)"

Broadened social awareness ( $10 \%$ of the male respondents; $4 \%$ of the females respondents)

"Gives insight into human behaviour"

"It broadens one's perspective"

"It gives basic human understanding"

The positive and negative attitudes of the graduates towards the sociology undergraduate programme have been cross-tabulated with their occupation and their current employment status.

Both male and female graduates in the dominant social welfare and teaching professions 
have high proportions expressing positive attitudes towards repeating the sociology undergraduate programme. Among males there is a weak significant relationship between attitude towards the programme and current employment status. Again one might argue that undergraduates with career aspirations towards social welfare occupations have been selected into the sociology programme that they perceive as offering them the courses they need for their chosen career. Those who are negative in their attitudes towards the programme tend to see sociology as not being practical enough for the work world, especially the business world.

\section{How do sociology graduates differ from other graduates?}

A rough basis for comparison between sociology graduates and graduates from other disciplines in the faculty of arts and in other faculties in terms of their post-graduate employment has been provided by a recent study of university graduates of the two years 1976 and 1977 , conducted by the student services department of the university at the same time as the present follow-up of sociology graduates. This study has a response rate of approximately $25.30 \%$. It shows that, whereas many graduates who majored in arts faculty disciplines such as English, history, modern languages, have, like sociology majors, gone to a school of education to prepare for a teaching career, those who do not become teachers, unlike the sociology majors who are concentrated in social welfare occupations, are engaged in a wide variety of occupations ranging from bank teller, postal clerk, library assistant, secretary, sales supervisor, life underwriter, title searcher, to office manager, assistant director of a student residence, executive assistant to a cabinet minister. By comparison, sociology appears to prepare people for (or select people who aspire to) social welfare jobs. The returns indicate no difference in unemployment rate among the disciplines (few respondents reported unemployment).

In all, the response rate for graduates of the faculty of education is $26 \%$. Of these $11.7 \%$ are unemployed, $7.8 \%$ are substitute teaching, and $9.0 \%$ indicated non-teaching jobs. Among the sociology graduates of comparable years with a B.Ed. degree only one woman is unemployed, although 3 women are substitute teaching.

Some of the respondents in my study who are negative in their attitudes towards the undergraduate programme in sociology and its contribution to their life and work experience indicate that commerce seems more practical to them, especially in terms of job opportunities. The university study has a response rate of $27 \%$ for accounting, $24 \%$ for business, and $17 \%$ for economics graduates in the faculty of commerce. Of these respondents, $100 \%$ of the accountant graduates report employment $(10 \%$ are unemployed and $10 \%$ are in education), and $100 \%$ of the economics graduates are employed. These data indicate that for the present at least, accounting and economics do guarantee job opportunities on completion of a first degree. How long will it last? Surely there is a saturation point for accountants in our finance dominated society?

\section{Who are the graduates?}

The data provide a profile of the sociology graduates in terms of selected background variables: sex, age, parental occupation, migratory history. Comparable data for other graduates of the university are not available. 
TABLE 4

DISTRIBUTION OF GRADUATES AND RESPONDENTS

BY YEAR OF GRADUATION, BY SEX

\begin{tabular}{|c|c|c|c|c|c|c|c|}
\hline \multirow{2}{*}{$\begin{array}{l}\text { Year of } \\
\text { graduation }\end{array}$} & \multicolumn{3}{|c|}{ Sociology graduates } & \multicolumn{3}{|c|}{ Respondents } & \multirow{2}{*}{$\begin{array}{l}\text { Response } \\
\text { rate by } \\
\text { year }\end{array}$} \\
\hline & MaIe & Female & Total & Male & Female & Total & \\
\hline 1971 & $\begin{array}{l}17.4 \\
(21)\end{array}$ & $\begin{array}{c}5.5 \\
(8)\end{array}$ & $\begin{array}{l}10.9 \\
(29)\end{array}$ & $\begin{array}{l}17.2 \\
(11)\end{array}$ & $\begin{array}{l}4.9 \\
(3)\end{array}$ & $\begin{array}{l}11.2 \\
(1.4)\end{array}$ & $48.2 \%$ \\
\hline 1972 & $\begin{array}{l}14.9 \\
(18)\end{array}$ & $\begin{array}{l}18.5 \\
(27)\end{array}$ & $\begin{array}{l}16.9 \\
(45)\end{array}$ & $\begin{array}{l}17.2 \\
\text { (1i) }\end{array}$ & $\begin{array}{l}11.5 \\
(7)\end{array}$ & $\begin{array}{l}14.4 \\
(18)\end{array}$ & $40.0 \%$ \\
\hline 1973 & $\begin{array}{l}18.2 \\
(22)\end{array}$ & $\begin{array}{l}11.0 \\
(16)\end{array}$ & $\begin{array}{l}14.2 \\
(38)\end{array}$ & $\begin{array}{l}18.8 \\
(12)\end{array}$ & $\begin{array}{l}11.5 \\
(7)\end{array}$ & $\begin{array}{l}15.2 \\
(19)\end{array}$ & $50.0 \%$ \\
\hline 1974 & $\begin{array}{l}18.2 \\
(22)\end{array}$ & $\begin{array}{l}16.4 \\
(24)\end{array}$ & $\begin{array}{l}17.2 \\
(46)\end{array}$ & $\begin{array}{l}21.9 \\
(14)\end{array}$ & $\begin{array}{l}13.1 \\
(8)\end{array}$ & $\begin{array}{l}17.6 \\
(22)\end{array}$ & $47.8 \%$ \\
\hline 1975 & $\begin{array}{r}9.9 \\
(12)\end{array}$ & $\begin{array}{l}18.5 \\
(27)\end{array}$ & $\begin{array}{l}14.6 \\
(38)\end{array}$ & $\begin{array}{l}4.7 \\
(3)\end{array}$ & $\begin{array}{l}23.0 \\
(14)\end{array}$ & $\begin{array}{l}13.6 \\
(17)\end{array}$ & $43.6 \%$ \\
\hline 1976 & $\begin{array}{l}13.1 \\
(16)\end{array}$ & $\begin{array}{l}17.8 \\
(26)\end{array}$ & $\begin{array}{l}15.7 \\
(42)\end{array}$ & $\begin{array}{l}12.5 \\
(8)\end{array}$ & $\begin{array}{l}18.0 \\
(11)\end{array}$ & $\begin{array}{l}15.2 \\
(19)\end{array}$ & $45.2 \%$ \\
\hline 1977 & $\begin{array}{r}8.3 \\
(10)\end{array}$ & $\begin{array}{l}12.3 \\
(18)\end{array}$ & $\begin{array}{l}10.5 \\
(28)\end{array}$ & $\begin{array}{l}7.8 \\
(5)\end{array}$ & $\begin{array}{l}18.0 \\
(11)\end{array}$ & $\begin{array}{l}12.8 \\
(16)\end{array}$ & $57.1 \%$ \\
\hline \multirow[t]{2}{*}{ Total } & $100.0 \%$ & $100.0 \%$ & & $100.0 \%$ & $100.0 \%$ & & \\
\hline & (121) & $(146)$ & $(267)$ & $(64)$ & $(61)$ & (125) & $46.8 \%$ \\
\hline Row total & $45.3 \%$ & $54.7 \%$ & $100.0 \%$ & $51.2 \%$ & $48.8 \%$ & $100.0 \%$ & \\
\hline
\end{tabular}

$\operatorname{Sex}$

Although there is an approximately equal sex distribution among the respondents ( $51 \%$ males and $49 \%$ females), the male-female proportions have been inverted over the years, with the 1974 graduating year as the turning-point. Whereas $75 \%$ of the male respondents graduated between 1971 and $1974,75 \%$ of the female respondents graduated between 1974 and 1977 . These responses reflect the sex composition of the graduate population: $69 \%$ of the males graduated between 1971 and $1974 ; 65 \%$ of the females graduated between 1974 and 1977 . The year 1972 (the first graduating class after the university became co-educational in 1968 marks a peak for female graduates. Table 4 compares the graduate population and the respondents by graduation year and by sex and shows the increasing participation of females.

Age

Female respondents are younger than males, as Table 5 shows. 
TABLE 5

DISTRIBUTION OF RESPONDENTS BY AGE BY SEX

\begin{tabular}{|c|c|c|c|c|c|c|}
\hline \multirow[t]{2}{*}{ Age Category } & \multicolumn{2}{|c|}{ Male } & \multicolumn{2}{|c|}{ Female } & \multicolumn{2}{|c|}{ Total } \\
\hline & No. & $\%$ & No. & $\%$ & No. & $\%$ \\
\hline $21-24$ years & 13 & 20.3 & 30 & 49.2 & 43 & 34.4 \\
\hline $25-29$ years & 31 & 48.4 & 25 & 41.0 & 56 & 44.8 \\
\hline 30 and over & 20 & 31.3 & 6 & 9.8 & 26 & 20.8 \\
\hline Total & 64 & 100.0 & 61 & 100.0 & 125 & 100.0 \\
\hline & $\begin{array}{l}\text { Mean }=2 \\
\text { Mode }=2 \\
\text { Median }\end{array}$ & $\begin{array}{l}68 \text { yrs. } \\
00 \\
7.83\end{array}$ & $\begin{array}{l}\text { Mean }= \\
\text { Mode }= \\
\text { Mediar }\end{array}$ & $\begin{array}{l}38 \text { yrs. } \\
.00 \\
24.56\end{array}$ & $\begin{array}{l}\text { Mean= } \\
\text { Mode= } \\
\text { Medi: }\end{array}$ & $\begin{array}{l}7.56 \text { yrs. } \\
4.00 \\
=26.45\end{array}$ \\
\hline
\end{tabular}

The median age for females is 24.6 years, as compared to 27.8 for males. One possible interpretation for these sex differences in age may be that more males than females are graduating in sociology after experience in the work world. On the other hand, the age differences by sex may simply reflect the weighting of male graduates from the four earliest years.

\section{Parental occupation}

The occupations of the graduates have been analysed in terms of their relationship to the occupations of their fathers and of their mothers. Both males and females have high percentages of their fathers in managerial and professional occupations (33\% of the fathers of males, and $41 \%$ of the fathers of females). On the other hand, $25 \%$ of the male graduates and $30 \%$ of the female graduates have fathers in crafts and trades. It is among the graduates who are teachers (especially the males) that the greatest upward mobility is observed. The fathers of nearly half $(42 \%)$ of the male teachers were employed in crafts and trades. On the other hand, fathers of graduates who are social welfare workers tend to be in greater proportions from the white collar work world. Part of this social mobility of the graduates is undoubtedly attributable to structural mobility through changes in the underlying occupational structure, although Rhinehart (1975:84-88) contends that the increase in white collar jobs in the Canadian labour force has been at the expense of agriculture and not blue-collar jobs, and that most young people are over-educated and over-trained for their jobs today.

The data have been analysed to see whether the fact that the graduate's mother is working or has ever worked outside the home has had any influence on the graduate pursuing education beyond the B.A. degree in sociology. Although there is no significant influence for males or females, it is to be noted that among females, a greater proportion 
TABLE $6 \mathrm{a}$

OCCUPATION OF RESPONDENTS BY FATHER'S OCCUPATION

\begin{tabular}{|c|c|c|c|c|c|c|c|c|c|c|}
\hline \multirow{2}{*}{$\begin{array}{l}\text { Father's } \\
\text { occupational } \\
\text { category }\end{array}$} & \multicolumn{9}{|c|}{ Respondent's occupational category } & \multirow[b]{2}{*}{ Total } \\
\hline & Manager & Teacher & $\begin{array}{l}\text { Religion } \\
\text { health }\end{array}$ & $\begin{array}{r}\text { Social } \\
\text { welfare }\end{array}$ & $\begin{array}{c}\text { Other } \\
\text { professional }\end{array}$ & $\begin{array}{c}\text { Clerical } \\
\text { sales }\end{array}$ & $\begin{array}{c}\text { Service } \\
\text { communication }\end{array}$ & Housework & Student & \\
\hline & $(N=8)$ & $(\mathrm{N}=36)$ & $(\mathrm{N}=4)$ & $(\mathrm{N}=34)$ & $(\mathrm{N}=3)$ & $(\mathrm{N}=8)$ & $(\mathrm{N}=4)$ & $(\mathrm{N}=1)$ & $(\mathrm{N}=17)$ & $(\mathrm{N}=115)$ \\
\hline Manager & $\begin{array}{l}37.5 \\
(3)\end{array}$ & $\begin{array}{l}25.0 \\
(9)\end{array}$ & & $\begin{array}{l}23.5 \\
(8)\end{array}$ & $\begin{array}{l}66.7 \\
(2)\end{array}$ & $\begin{array}{l}12.5 \\
(1)\end{array}$ & $\begin{array}{l}25.0 \\
(1)\end{array}$ & & $\begin{array}{l}35.3 \\
(6)\end{array}$ & $\begin{array}{c}26.0 \\
(30)\end{array}$ \\
\hline $\begin{array}{l}\text { Professional, } \\
\text { technical. }\end{array}$ & $\begin{array}{l}12.5 \\
(1)\end{array}$ & $\begin{array}{l}5.6 \\
(2)\end{array}$ & & $\begin{array}{l}17.7 \\
(6)\end{array}$ & $\begin{array}{l}33.3 \\
(1)\end{array}$ & $\begin{array}{l}25.0 \\
(2)\end{array}$ & & & & $\begin{array}{c}10.4 \\
(12)\end{array}$ \\
\hline Clerical, sales & $\begin{array}{l}12.5 \\
(1)\end{array}$ & $\begin{array}{l}2.8 \\
(1)\end{array}$ & & $\begin{array}{l}11.8 \\
(4)\end{array}$ & & & & $\begin{array}{l}100.0 \\
(1)\end{array}$ & $\begin{array}{l}17.7 \\
(3)\end{array}$ & $\begin{array}{l}8.7 \\
(10)\end{array}$ \\
\hline Service & & $\frac{11.1}{(4)}$ & $\begin{array}{l}25.0 \\
(1)\end{array}$ & $\begin{array}{l}14.7 \\
(5)\end{array}$ & & & $\begin{array}{l}75.0 \\
(3)\end{array}$ & & $\begin{array}{l}5.8 \\
(1)\end{array}$ & $\begin{array}{l}12.2 \\
(14)\end{array}$ \\
\hline $\begin{array}{l}\text { Transportation } \\
\text { communications }\end{array}$ & $\begin{array}{l}12.5 \\
(1)\end{array}$ & $\begin{array}{l}8.3 \\
(3)\end{array}$ & $\begin{array}{l}25.0 \\
(1)\end{array}$ & $\begin{array}{l}2.9 \\
(1)\end{array}$ & & $\begin{array}{l}12.5 \\
(1)\end{array}$ & & & $\begin{array}{l}17.7 \\
(3)\end{array}$ & $\begin{array}{r}8.7 \\
(10)\end{array}$ \\
\hline $\begin{array}{l}\text { Farming, fishing, } \\
\text { mining }\end{array}$ & $\begin{array}{l}12.5 \\
(1)\end{array}$ & $\begin{array}{l}11.1 \\
(4)\end{array}$ & & $\begin{array}{l}5.9 \\
(2)\end{array}$ & & $\begin{array}{l}12.5 \\
(1)\end{array}$ & & & & $\begin{array}{l}7.0 \\
(8)\end{array}$ \\
\hline Crafts and trades & $\begin{array}{l}12.5 \\
(1)\end{array}$ & $\begin{array}{l}36.1 \\
(13)\end{array}$ & $\begin{array}{l}50.0 \\
(2)\end{array}$ & $\begin{array}{l}23.5 \\
(8)\end{array}$ & & $\left.{ }^{37}\right)^{5}$ & & & $\begin{array}{l}23.5 \\
(4)\end{array}$ & $\begin{array}{l}27.0 \\
(31)\end{array}$ \\
\hline Total & $100.0 \%$ & $100.0 \%$ & $100.0 \%$ & $100.0 \%$ & $100.0 \%$ & $100.0 \%$ & $100.0 \%$ & $100.0 \%$ & $100.0 \%$ & $100.0 \%$ \\
\hline
\end{tabular}

Chi square $=70.43682$

Significance $=\quad .0928$ 
TABLE $6 b$

OCCUPATION OF MALE RESPONDENTS BY FATHER'S OCCUPATION

\begin{tabular}{|c|c|c|c|c|c|c|c|c|c|}
\hline \multirow{3}{*}{$\begin{array}{l}\text { Father's } \\
\text { occupational } \\
\text { category }\end{array}$} & \multicolumn{8}{|c|}{ Respondent's occupational category } & \multirow[b]{2}{*}{ Tota1 } \\
\hline & Manager & Teacher & $\begin{array}{l}\text { Religion, } \\
\text { health }\end{array}$ & $\begin{array}{r}\text { Social } \\
\text { welfare }\end{array}$ & $\begin{array}{l}\text { Other } \\
\text { professional }\end{array}$ & $\begin{array}{l}\text { Clerical } \\
\text { sales }\end{array}$ & $\begin{array}{l}\text { Service, } \\
\text { communicator }\end{array}$ & Student & \\
\hline & $(N=8)$ & $(N=12)$ & $(\mathrm{N}=3)$ & $(\mathrm{N}=19)$ & $(\mathrm{N}=2)$ & $(\mathrm{N}=3)$ & $(N=4)$ & $(\mathrm{N}=10)$ & $(N=61)$ \\
\hline Manager & $\begin{array}{l}37.5 \\
(3)\end{array}$ & $\begin{array}{l}25.0 \\
(3)\end{array}$ & & $\begin{array}{l}21.1 \\
(4)\end{array}$ & $\begin{array}{l}50.0 \\
(1)\end{array}$ & & $\begin{array}{l}25.0 \\
(1)\end{array}$ & $\begin{array}{l}20.0 \\
(2)\end{array}$ & $\begin{array}{c}22.9 \\
(14)\end{array}$ \\
\hline $\begin{array}{c}\text { Professional, } \\
\text { technical }\end{array}$ & $\begin{array}{l}12.5 \\
(1)\end{array}$ & & & $\begin{array}{l}15.8 \\
(3)\end{array}$ & $\begin{array}{l}50.0 \\
(1)\end{array}$ & $\begin{array}{l}33.3 \\
(1)\end{array}$ & & & $\begin{array}{l}9.8 \\
(6)\end{array}$ \\
\hline Clerical, sales & $\frac{12.5}{(1)^{5}}$ & $\begin{array}{l}8.3 \\
(1)\end{array}$ & & $\begin{array}{l}10.5 \\
(2)\end{array}$ & & & & $\begin{array}{l}30.0 \\
(3)\end{array}$ & $\begin{array}{c}11.5 \\
(7)\end{array}$ \\
\hline Service & & & $\begin{array}{l}33.3 \\
(1)\end{array}$ & $\begin{array}{l}26.3 \\
(5)\end{array}$ & & & $\begin{array}{l}75.0 \\
(3)\end{array}$ & $\begin{array}{l}10.0 \\
(1)\end{array}$ & $\begin{array}{c}16.4 \\
(10)\end{array}$ \\
\hline $\begin{array}{l}\text { Transportation, } \\
\text { communications }\end{array}$ & $\begin{array}{l}12.5 \\
(1)\end{array}$ & $\begin{array}{l}16.7 \\
(2)\end{array}$ & & & & & & $\begin{array}{l}20.0 \\
(2)\end{array}$ & $\begin{array}{l}8.2 \\
(5)\end{array}$ \\
\hline $\begin{array}{l}\text { Farming, fishing, } \\
\text { mining }\end{array}$ & $\begin{array}{l}12.5 \\
(1)\end{array}$ & $\begin{array}{l}8.3 \\
(1)\end{array}$ & & $(1)^{5.3}$ & & $\begin{array}{l}33.3 \\
(1)\end{array}$ & & & $\begin{array}{l}6.6 \\
(4)\end{array}$ \\
\hline Crafts and Trades & $\begin{array}{l}12.5 \\
(1)\end{array}$ & $\begin{array}{l}41.7 \\
(5)\end{array}$ & $\begin{array}{l}67.7 \\
(2)\end{array}$ & $\begin{array}{l}21.0 \\
(4)\end{array}$ & & $\begin{array}{l}33.4 \\
(1)^{4}\end{array}$ & & $\begin{array}{l}20.0 \\
(2)\end{array}$ & $\begin{array}{l}24.6 \\
(15)\end{array}$ \\
\hline Total & $100.0 \%$ & $100.0 \%$ & $100.0 \%$ & $100.0 \%$ & $100.0 \%$ & $100.0 \%$ & $100.0 \%$ & $100.0 \%$ & $100.0 \%$ \\
\hline
\end{tabular}


TABLE $6 \mathrm{C}$

OCCUPATION OF FEMALE RESPONDENTS BY FATHER'S OCCUPATION

\begin{tabular}{|c|c|c|c|c|c|c|c|c|c|}
\hline \multirow{3}{*}{$\begin{array}{l}\text { Father's } \\
\text { occupational } \\
\text { category }\end{array}$} & \multicolumn{8}{|c|}{ Respondent's occupational category } & \multirow[b]{2}{*}{ Total } \\
\hline & Teacher & $\begin{array}{l}\text { Religion } \\
\text { health }\end{array}$ & $\begin{array}{r}\text { Social } \\
\text { welfare }\end{array}$ & $\begin{array}{c}\text { Other } \\
\text { professional }\end{array}$ & $\begin{array}{l}\text { Clerical, } \\
\text { Sales }\end{array}$ & $\begin{array}{c}\text { Service } \\
\text { communicator }\end{array}$ & Housework & Student & \\
\hline & $(N=24)$ & $(N=1)$ & $(N=15)$ & $(\mathrm{N}=1)$ & $(N=5)$ & & $(N=1)$ & $(N=7)$ & $(\mathrm{N}=54)$ \\
\hline Manager & $\begin{array}{l}25.0 \\
(6)\end{array}$ & & $\begin{array}{l}26.7 \\
(4)\end{array}$ & $\begin{array}{l}100.0 \\
(1)\end{array}$ & $\begin{array}{l}20.0 \\
(1)\end{array}$ & & & $\begin{array}{l}57.1 \\
(4)\end{array}$ & $\begin{array}{l}29.6 \\
(16)\end{array}$ \\
\hline $\begin{array}{l}\text { Professional, } \\
\text { technical }\end{array}$ & $\begin{array}{l}8.3 \\
(2)\end{array}$ & & $\begin{array}{l}20.0 \\
(3)\end{array}$ & & $\begin{array}{l}20.0 \\
(1)\end{array}$ & & & & $\begin{array}{l}11.1 \\
(6)\end{array}$ \\
\hline Clerical, sales & & & $\begin{array}{l}13.3 \\
(2)\end{array}$ & & & & $\begin{array}{l}100.0 \\
(1)\end{array}$ & & $\begin{array}{l}5.6 \\
(3)\end{array}$ \\
\hline Service & $\begin{array}{l}16.7 \\
(4)\end{array}$ & & & & & & & & $\begin{array}{l}7.4 \\
(4)\end{array}$ \\
\hline $\begin{array}{l}\text { Transportation, } \\
\text { communication }\end{array}$ & $\begin{array}{l}4.2 \\
(1)^{2}\end{array}$ & $\begin{array}{l}100.0 \\
(1)\end{array}$ & $\begin{array}{l}6.7 \\
(1)\end{array}$ & & $\begin{array}{l}20.0 \\
(1)\end{array}$ & & & $\begin{array}{l}14.3 \\
(1)\end{array}$ & $\begin{array}{l}9.3 \\
(5)\end{array}$ \\
\hline $\begin{array}{l}\text { Farming, fishing, } \\
\text { mining }\end{array}$ & $\begin{array}{l}12.5 \\
(3)\end{array}$ & & $\begin{array}{l}6.7 \\
(1)\end{array}$ & & & & & & $\begin{array}{l}7.4 \\
(4)\end{array}$ \\
\hline Crafts and trades & $\begin{array}{l}33.3 \\
(8)\end{array}$ & & $\begin{array}{l}26.6 \\
(4)\end{array}$ & & $\begin{array}{l}40.0 \\
(2)\end{array}$ & & & $\begin{array}{l}28.6 \\
(2)\end{array}$ & $\begin{array}{l}29.6 \\
(16)\end{array}$ \\
\hline Total & $100.0 \%$ & $100.0 \%$ & $100.0 \%$ & $100.0 \%$ & $1.00 .0 \%$ & & $100.0 \%$ & $100.0 \%$ & $100.0 \%$ \\
\hline
\end{tabular}


TABLE 7

INFLUENCE OF MOTHER'S WORK ON GRADUATES'

FURTHER EDUCATION, SEX CONTROLLED

\begin{tabular}{|c|c|c|c|}
\hline \multirow[b]{2}{*}{$\begin{array}{l}\text { Post-graduate } \\
\text { education }\end{array}$} & \multicolumn{2}{|c|}{ Mother's Work } & \\
\hline & $\begin{array}{l}\text { Outside } \\
\text { home } \\
(\mathrm{N}=53)\end{array}$ & $\begin{array}{l}\text { Inside } \\
\text { home } \\
(\mathrm{N}=69)\end{array}$ & \\
\hline \multicolumn{4}{|l|}{ Total: $\quad(\mathrm{N}=122)$} \\
\hline Yes & $\begin{array}{l}60.4 \\
(32)\end{array}$ & $\begin{array}{l}75.4 \\
(52)\end{array}$ & $\begin{array}{l}\text { Chi square }=2.47873 \\
\text { Significance }=.11\end{array}$ \\
\hline No & $\begin{array}{l}39.6 \\
(21)\end{array}$ & $\begin{array}{l}24.6 \\
(17)\end{array}$ & $\mathrm{C}=.15837$ \\
\hline \multirow[t]{2}{*}{ Total } & $100.0 \%$ & $100.0 \%$ & \\
\hline & $43.4 \%$ & $56.6 \%$ & \\
\hline
\end{tabular}

Males $(N=63)$

\begin{tabular}{|c|c|c|c|}
\hline Yes & $\begin{array}{l}58.3 \\
(14)\end{array}$ & $\begin{array}{l}79.5 \\
(31)\end{array}$ & $\begin{array}{l}\text { Chi square }=2.30361 \\
\text { Significance }=.1 \text {.1? }\end{array}$ \\
\hline No & $\begin{array}{l}41.7 \\
(10)\end{array}$ & $\begin{array}{l}20.5 \\
(8)\end{array}$ & $\mathrm{C}=.22174$ \\
\hline \multirow[t]{2}{*}{ Total } & $100.0 \%$ & $100.0 \%$ & \\
\hline & $38.1 \%$ & $61.9 \%$ & \\
\hline
\end{tabular}

Females $(\mathrm{N}=59)$

\begin{tabular}{|c|c|c|c|c|}
\hline Yes & $\begin{array}{l}62.1 \\
\text { (18) }\end{array}$ & $\begin{array}{l}70.0 \\
(21)\end{array}$ & $\begin{array}{l}\text { Chi square } \\
\text { Significanee }\end{array}$ & $\begin{array}{l}13565 \\
=\quad .71\end{array}$ \\
\hline No & $\begin{array}{l}37.9 \\
(11)\end{array}$ & $\begin{array}{l}30.0 \\
(9)\end{array}$ & $\mathrm{C}$ & $=.0834$ \\
\hline \multirow[t]{2}{*}{ Total } & $100.0 \%$ & $100.0 \%$ & & \\
\hline & $49.2 \%$ & $50.8 \%$ & & \\
\hline
\end{tabular}

of mothers working outside the home may have had some influence on the girl's going to university in the first place. In terms of the occupations of the graduates, mother working outside the home or inside the home makes no difference for either males or females.

\section{Migratory history}

The data of the present study confirm the findings of other research that highly educated young adults also tend to be highly mobile (cf. Stone, 1969: 71; McInnes, 1971; 195). 
Among the respondents, $84 \%$ of the males and $79 \%$ of the females are migrants, having moved at some time in their lives from the county in which they were born. The survey gathered data on lifetime patterns of migration of the sociology graduates. Like most internal migration in Canada, migration is predominantly intra-provincial or intra-regional. The mode for the number of moves is 3 for males and 2 for females. Clearly much of the migration of these young adults has been as secondary migrants or companions to parents over a lifetime before they embarked on their own careers. In order to gather data on specifically career-oriented mobility, the respondents were asked if they had ever moved for job reasons and what type of job they took. Among males, 58\% migrated for job reasons; among females, $36 \%$. Almost half the females moved for a teaching job, whereas half the males moved for a job in some form of social welfare. Some few graduates have moved greater distances outside the region and the country and seem to have jobs of greater diversity than the average, and sometimes of higher income.

\section{What are the career expectations of the graduates?}

The results of the investigation of the career expectations of the graduates are crosstabulated with their post-graduate education in Table 8; however, these data do not adequately reflect the type of career mobility the graduates expect. With some rare exceptions (such as the woman who expects to be a farmer), most of the graduates tend to see their careers as being upwardly mobile through normal progression to administrative, supervisory, and managerial positions in the educational, social service, and public service sectors of society. For example, many teachers expect to be principals or other administrators; some social workers expect to be directing agencies or teaching in schools of social work. Present students expect careers in line with their post-graduate studies.

The women all seem to be oriented to work outside the home, even if presently unemployed (whether by choice for a vacation or to have a child, or by inability to find a job). On the other hand, they tend to be in traditional "women's occupations" or "semi-professions," and rarely in supervisory or administrative positions. As noted above, moreover, women tend to be teaching at the elementary or junior high level, and few aspire to administrative positions in education.

In general, the respondents seem to be looking forward to stability and security in their careers, or at least the $97(78 \%)$ graduates who completed this item. Perhaps the 12 males and 16 females who left the item blank or who wrote "who knows?" are more realistic in their attitudes to a problematic work world.

\section{DISCUSSION}

What are the implications of this study? The question can be approached from different perspectives: those of students, teachers, university administrators, governments. The survey was initiated through the desire of sociology faculty in a maritime university to have some "hard data" on the majors who had graduated in recent years. What do the results suggest for the teaching of sociology at the undergraduate level? Evaluation and planning should be directed towards the content of the programme (curricula, academic counseling, research activities, and the like), as well as towards actual and potential students (for example, part-time mature students). The data suggest a trend towards a 
TABLE 8

OCCUPATIONAL EXPECTATIONS BY POST-GRADUATE EDUCATION, SEX CONTROLLED

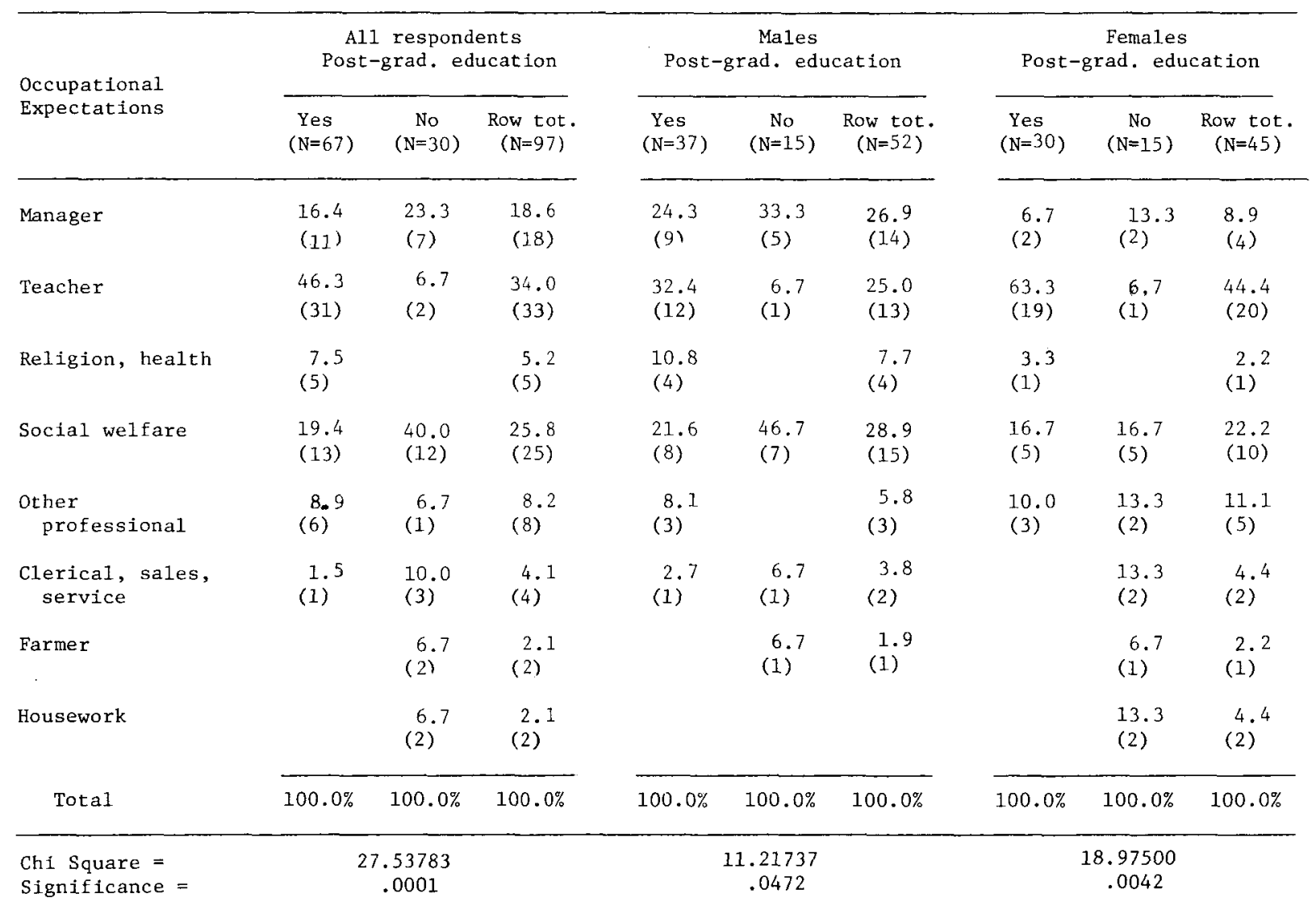


disproportionate number of relatively young female undergraduate sociology majors rather than males (although the current year has an equal number of male and feamle potential graduates). Female dominance in sociology undergraduate programmes has been the pattern for some time in the United States (U.S. Dept. of Labour, 1965; quoted in The American Sociologist, 1974: 111). Perhaps attention should be paid to providing a programme to meet the expectations of part-time older students presently in the work world and looking to learn the disciplinary skills that sociology can offer.

What are the implications for the student who majors in sociology? Are the students choosing a major with their primary focus on its marketability when, degree in hand, they attempt to enter the labour force? Or are they intent upon learning for learning's sake? Have they selected sociology as a major because they perceive it as providing the "theory" for the social work activities they aspire to as a career? The results suggest that the graduates' perceptions of what they have gained from their sociology courses might well be just as applicable to non-majors as to majors and useful in any chosen career. In other words, the graduates with positive attitudes towards their sociology programme have evaluated it less in terms of economic relevance than in terms of learning for its own sake.

As direct preparation for a career, sociology without any further professional training or continued education, from this study, seems to lead directly into the social welfare activities in a variety of social agencies in the community. If the potential major or graduate focuses on the marketability of a B.A. degree with a major in sociology, this is what the student would see. But what does the future hold for social welfare workers, who are often dependent on government grants for funding jobs in social agencies or special projects, now that government funds for such work are drying up? Perhaps we should devote more time and attention in our sociology curriculum to social research that is directed towards social policy and social planning. Such a shift in orientation is likely to meet with resistance, not least from the students who are more concerned with their own future when immediate employment prospects look dim.

In a province where there are no community colleges, the maritime university is not faced with the hierarchical division that often tends to exist between universities and community colleges. At the same time the university has greater responsibility for meeting educational needs of the larger community: providing access for the young and mature student; offering training for specialized skills in various community services; addressing itself to local problems and social issues. Sociology is a discipline particularly suited to meeting the two latter objectives: the present study has demonstrated the relevance of the programme (at least in the eyes of the graduates) for social research and social work occupations; the courses offered bring the discipline to bear upon such concerns as Atlantic studies, multiculturalism, regional development.

From the perspective of government, according to the Examiners who prepared the OECD (1975) Report, the most urgent need is the development of a Canadian educational policy that spells out the social goals of education in a period of history when there are other social tasks competing for scarce financial resources. Attention is no longer focussed on quantitative expansion but rather on the kind of knowledge that will be created and transmitted, the kind of issues that will be addressed, and who will be part of this process. The present study has been an attempt to evaluate one dimension of the past, the students who have followed a course of studies in sociology, with a view to planning for the future. 


\section{FOOTNOTES}

1. Data provided by the Regional Office of Statistics Canada, Halifax, Nova Scotia, in a telephone communication, April 27, 1978.

\section{REFERENCES}

Clinton, L. and K. Kincaid (1977) "Attitudes of sociology majors toward the discipline of Sociology." Paper presented at the South West Sociology Association, April 1977.

Crean, John F., Michael M. Ferguson, Hugh J. Somers, (1969) "Higher Education in the Atlantic Provinces for the 1970's: A Study Prepared under the Auspices of the Association of Atlantic Universities for the Maritime Union Study." Halifax.

Marchak, M. Pat, (1977) "The Canadian Labour Force: Jobs for Women." Pp. 148-159 in Marylee Stephenson, Women in Canada. Rev. edit. Don Mills, Ontario: General Publishing Co.

Marsden, Lorna, Edward Harvey, Ivan Charner, (1975) "Female graduates: their occupational mobility and attainments," Canadian Review of Sociology and Anthropology 124 Part 1: 385-405.

McInnis, Marvin, (1971) "Age, education and occupational differentials in inter-regional migration: Some evidence for Canada," Demography 82 (May): 195-204.

Organisation for Economic Co-operation and Development, (1976) Reviews of National Policies for Education: Canada. Paris: OECD.

Rhinehart, James W., (1975) The Tyranny of Work. Don Mills, Ontario: Longman Canada.

Stone, Leroy O., (1969) Migration in Canada: Regional Aspects. Ottawa: Queen's Printer. 